\title{
Augustinus oor staat (en kerk)
}

\author{
J.H. van Wyk \\ Skool vir Kerkwetenskappe \\ Potchefstroomse Universiteit vir $\mathrm{CHO}$ \\ POTCHEFSTROOM
}

\begin{abstract}
Augustine's views on state (and church)

It is no easy task to assess Augustine's views on state and church as there are as many interpretations as there are interpreters to these issues. From a study of Augustine himself, and especially his De civitate dei, it becomes evident that he did not follow the Manichean, Donatist or Tertullian view of total separation, neither the Origean, Eusebian or Ambrosian view of (a close) co-operation, but that he developed his own view which can be typified as critical realism. Sin, social context and the kingdom of God played a decisive role in forming his final perspectives - although we have to admit that in the Donatist disputes Augustine's attitude was very controversial.
\end{abstract}

\section{Inleiding}

Wanneer iemand 'n studie probeer maak van 'n reuse-figuur soos Augustinus, voel jy soms soos 'n drenkeling op 'n wye oseaan waar jy letterlik geen oewers sien nie. Die seestrome voer jou soms verby ruwe landskappe, maar ook verby paradyseilande en oor asemrowende mooi koraalriwwe. Nooit raak dit vervelig om jou besig te hou met hierdie grootste teoloog uit Afrika en waarskynlik ook van die Westerse teologie nie. Die vraag ontstaan dan onwillekeurig: het hierdie kerkvader uit Noord-Afrika iets te sê vir die kerk en teologie in Suid-Afrika vandag?

\subsection{Kontekstualisering}

Wanneer Augustinus bestudeer word, veral ten opsigte van die verhouding van die staat en die kerk, moet 'n aantal belangrike aspekte duidelik verdiskonteer word. Ek noem slegs drie daarvan. 
- Eerstens moet verreken word dat Augustinus 'n bepaalde teologiese ontwikkeling deurgemaak het. Sy ontdekking van Paulus se sonde- en genadeleer rondom 396 het 'n byna Kopernikaanse omwenteling in sy denke tot gevolg gehad (Markus, 1988:x-xi). Hy het van daardie tyd af wegbeweeg van 'n optimistiese antropologie en samelewingsbeskouing na 'n veel meer "pessimistiese" - soms ook genoem "realistiese" - benadering (vgl. Engelbrecht, 1985:86, 95; Niebuhr, 1986:123-141; Geerlings, 1997:215; Höffe, 1997:279; Rist, 1999:205210 225). Die sonde - en genade - het 'n al hoe groter plek in sy teologiese denke begin inneem en dit het in sy latere ontwikkeling momentum gekry vanweë die anti-Pelagiaanse stryd.

- Tweedens moet die verskuiwende politieke konteks wat Augustinus meegemaak het, ook in berekening gebring word. Waar hy in sy vroeëre denke tydens die Pax Romana maklik aansluiting kon vind by die Eusebiaanse en Originesiaanse triomfantalistiese staatsbeskouing, waar die Romeinse staat gesien is as deel van God se heilsplan om die Christendom te versprei en waar die samelewing die koninkryk van God bekendstel en bevorder, daar het die val van Rome in 410 'n teologiese aardskudding veroorsaak en 'n nuwe oriëntasie op die staat en kerk genoodsaak (Rist, 1999:217). Augustinus begin kort hierna werk aan sy magistrale werk De civitate dei (412-426) waarin hy in die eerste tien boeke die ongegronde menings van die heidene teen die Christendom weerlê en aantoon dat die val van Rome geleë is in sedelike dekadensie en menslike hoogmoed, asook dat die evangelie nie staatsondermynend is nie. In die laaste twaalf boeke handel hy oor die ontstaan, ontwikkeling en eindbestemming van die twee stede, die civitas Dei en die terrena civitas (vgl. Duchrow, 1970: 83-319).

- Derdens moet verreken word dat Augustinus sterk deur die filosofie van (veral) die Neo-Platonisme beïnvloed is en dat hierdie invloed sy merk op sy teologiese denke gemaak het. In sy antropologie, kosmologie en politikologie slaan dit telkens deur, hoewel dit telkens getemper en gekorrigeer word deur sy teologiese insigte.

\subsection{Modellering}

Ter wille van 'n duideliker reliëf van ons besinning, kan dit waardevol wees om enkele belangrike (ou en moderne) modelle van die verhouding staat-en-kerk uit te spel (vgl. Van Wyk, 1991:205-212, 213-244; Van Wyk, 1998:151-154; Van Wyk, 1999:55-62). Hierdie agtergrond kan daartoe bydra om Augustinus beter te verstaan en makliker te plaas. Uiteraard word in hierdie verband net die hooflyne weergegee. Verder 
moet in gedagte gehou word dat die denklyne soms oorvleuel en nie absoluut van mekaar afgegrens kan word nie.

- Die eerste model is dié van (mindere of meerdere) identifikasie van staat en kerk. In hierdie benadering is die staat die politieke gestalte van die kerk en die kerk die godsdienstige gestalte van die staat. Staat en kerk leef so na aan mekaar dat die onderskeid tussen albei vervaag en soms verdwyn. Vergelyk in hierdie verband die teokratiese model van oud-Israel asook die staats- en volkskerkgedagte. Verder kan ook gedink word aan die uitbou en propagering van die Christelike godsdiens in die vierde eeu deur keiser Konstantyn en Theodosius.

- Die tweede model is dié van separasie van staat en kerk, 'n model met verskeie nuanses, soos byvoorbeeld te sien is in die Lutherse benadering (skeiding), die Calvinistiese siening (onderskeiding maar ook verband) en in die Anabaptistiese ontwerp (radikale skeiding).

- 'n Derde model is dié van dominasie/supremasie. In hierdie benadering heers die staat oor die kerk (staatsabsolutisme) of die kerk oor die staat (kerkisme).

- 'n Vierde model is pluralisme, waar staat en kerk beskou word as twee lewensfere, elk met sy eie taak en bevoegdheid. Hulle is van mekaar onderskeie, maar het ook duidelike raakvlakke.

Navorsers wys daarop dat Augustinus verskillende denklyne, wat voor hom gegeld het, kon gevolg het. Daar was byvoorbeeld die gedagterigting van Plato en Aristoteles wat van mening was dat dit die staat se taak is om goeie burgers te kweek (Rist, 1999:207). Daar was die dualistiese benadering van die Manicheïsme wat al wat aards is onderwaardeer het, asook die benadering van die Donatiste met hulle radikale skeiding van kerk (sakraal) en wêreld (sekulêr) (Markus, 1988:122). Vóór Augustinus was daar basies twee denklyne: 'n kritiese lyn, soos verteenwoordig deur Hippolitus en Tertullianus, wat die staat as vyand van die kerk beskou het (die staat as dier), en 'n waarderende lyn, te vind by Origines, Eusebius, Ambrosius en Hieronimus, waar die staat gesien is as vriend van die kerk (die staat as dienaar) (vgl. Markus, 1988:45-52). Die vraag bly dus: het Augustinus sy eie weg gegaan of het hy by sommige van hierdie beskouings aansluiting gevind?

\subsection{Algemene opmerkings}

Voordat oorgegaan word na die behandeling van ons tema, moet nog enkele belangrike voorafopmerkings gemaak word. 
- In die bespreking van Augustinus se gedagtes oor staat en kerk, gaan veral gefokus word op sy gerypte werk, De civitate dei.

- In die benadering gaan die aksent val op sy "staatsleer" en die verhouding van die staat tot die kerk eerder as op sy kerkleer en die verhouding van die kerk tot die staat. Augustinus se standpunt is in hierdie verband getipeer as pessimisme, realisme, neutralisme en negativisme en die vraag onstaan of hierdie tiperings geldig is.

- Die begrip staat is 'n wollerige begrip wat soms slaan op 'n regering, soms op die regering en onderdane, soms op die samelewing, ensovoorts. Ter wille van gemak maak ons deurgaans gebruik van die begrip staat, maar die konteks sal telkens die betekenis daarvan bepaal.

- Soos uit die vervolg sal blyk, bestaan daar uiteenlopende en selfs teenstrydige interpretasies van die teologie van Augustinus. Suiwer objektiwiteit is natuurlik nie moontlik nie, want elke teoloog lees Augustinus deur die bril van sy eie teologiese denkraamwerk. Daarmee is natuurlik nie vir 'n suiwer subjektiwistiese benadering gekies nie, maar vir 'n aanpak waarin afwisselend na die hoofteks en bytekste gekyk sal word. In hierdie verband kan verwys word na verskeie belangrike interpretasies van Augustinus se staatsbeskouing, in boeke ${ }^{1}$ en artikels ${ }^{2}$, asook oor sy kerkleer, in boeke ${ }^{3}$ en artikels 4 .

- In hierdie benadering gaan enkele sentrale temas wat vir die staatsleer en die verhouding staat-en-kerk belangrik is, ondersoek en bespreek word, gevolg deur 'n samevatting en evaluering.

$1 \quad$ Vgl. onder andere Figgis, 1921; Baynes, 1936; Friberg, 1944; Marshall, 1952; Deane, 1963; Brown, 1972; Markus, 1988; Elshtain, 1995.

2 Vgl. Engelbrecht, 1985; Niebuhr, 1986; Ruokanen, 1988; TeSelle, 1991; Dyson, 1998: xv-xxxiii.

3 Vgl. onder andere Hofmann, 1933; Ratzinger, 1954; Grabowski, 1957.

$4 \quad$ Vgl. Van Bavel, 1976; Van Oort, 1990; Fahey, 1992 (oorsigtelik). 


\section{Augustinus oor staat (en kerk)}

\subsection{Die staat as ryk van die duiwel?}

Augustinus se staatsfilosofie - vir sover daarvan gepraat kan word moet sekerlik verstaan word binne die konteks van sy twee-stedeteorie, die civitas dei en die terrena civitas.

Dis duidelik dat Augustinus die twee stede identifiseer met twee lewenswyses, naamlik as 'n lewenswyse na die vlees en 'n lewe na die Gees (DCD 14:2; 14:4, 9), as 'n lewe volgens die mens en 'n lewe volgens God (DCD 14:4; 15:8), as 'n lewe uit selfliefde en 'n lewe uit Godsliefde (DCD 14:13; 15:3), as 'n lewe in selfroem en 'n lewe in Godsroem (DCD 14:28); in die een stad word net gebore, in die ander stad word ook wedergebore (DCD 15:16, 20). Al word van 'n "hemelse stad" gepraat, is ('n deel van) die burgers op aarde - en wel as vreemdelinge - op weg na die hemelse vaderland (DCD 15:1). Die civitas dei bestaan uit die goeie engele en al die uitverkorenes terwyl die terrena civitas uit die slegte engele en die verlorenes bestaan. Op aarde, in die menslike samelewing (of saeculum) bestaan die twee stede egter vervleg en vermeng (DCD 10:32; 11:1; 16:10, 54) (vgl. Markus 1988: 133).

Die hemelse stad val nie (volledig) saam met die begrip kerk nie, want die kerk is 'n corpus permixtum, en die aardse stad val ook nie saam met die begrip staat nie, want ook die staat bestaan uit 'n gemengde samelewing (Grabowski, 1957:456; Markus 1988:59; Ruokanen, 1988:25; De Kruijf, 1994:60-61). Die terrena civitas is ook nie identies aan die civitas diaboli nie, al kon Augustinus harde woorde oor onregverdige state (Assirië en Rome) uitspreek. Al twee ryke kan nie met sigbare mensegroepe of institute geïdentifiseer word nie.

Die onderskeiding wat Augustinus tussen die twee stede gemaak het, is dus ' $n$ spirituele en geen geografiese onderskeiding nie (Douma, 1984: 28, 39): dit gaan oor die stryd tussen twee liefdes, twee wille, twee gelowe; dit gaan oor wat mense liefhet (God of hulleself), wat hulle glo (God of afgode), wat hulle wil (die goeie of die kwade).

Albei ryke gaan terug op 'n versteurde liefdesordening. Die aardse ryk rus op selfliefde (amor sui), begeerte (cupiditas) en hoogmoed (superbia), wat alles manifesteer in magslus (libido dominandi). Die liefde waarvan Augustinus praat, is 'n geordende liefde (DCD 15:22): God bo alles, die mens tweede (en dan ook 'n mensliefde wat bemiddel is deur die Godsliefde). Die bose is vir Augustinus ook nie geleë in die natuur nie - en dit is daarom geen substansie nie - maar in die wil van die mens. Rome se grondfout was nie net hebsug nie, maar veral roemsug, waaruit hoogmoed en magsug voortgespruit het (Höffe, 1997:267). 
Perverse selfliefde, gegrond in hoogmoed, is die fundamentele wanorde in die mens en in die samelewing. Waar die hemelstad gekenmerk word deur liefde en mededeelsaamheid, daar word die wêreldstad gekenmerk deur dominasie en eksploitasie. Tereg is opgemerk (TeSelle, 1991:153) dat Augustinus juis op die vlak van die "disordered human affections" een van sy "most lasting contributions" gemaak het.

Dit is duidelik dat die aardse staat nie outomaties 'n diaboliese staat hoef te wees nie, hoewel die duiwel dit natuurlik vir diaboliese doeleindes kan misbruik. Augustinus het egter nie 'n diaboliese staatsbeskouing op die aardse staat nagehou nie.

\subsection{Die staat as sonde-ordening}

Dit is waar dat Augustinus daarna kan verwys dat God die staat verordineer het (DCD 5:21), en dat die staat ook met die voorsienige bestel van God in verband gebring moet word (Markus, 1988:91), maar sy rypste verstaan daarvan is om dit met die sonde te verbind. Die staat is voor alles 'n teken van die samelewing wat in sonde geval is (Ruokanen, 1988:28; Rist, 1999:217, 252); regering moet verstaan word as voortspruitend uit selfliefde, magslus en nie-onderdanigheid teenoor God (DCD 19:15) en daarom kan nie van die staat verwag word om die morele waardes en deugde van die burgers te vorm of te verhoog nie (Höffe, 1997:284; Rist, 1999:224-225).

Augustinus verwerp - sedert 390 - die Griekse en Romeinse idee dat volmaaktheid deur middel van die polis bereik kan word en dat menslike wette die mens goed kan maak (Markus, 1988:83-89). Die regeringstaak is om wanorde te verminder, gewelddadigheid te beteuel, aardse vrede te bewaar en sodoende buffers te verskaf teen disintegrasie en chaos. Die staat moet magslus beheer (DCD 14:28).

Om saam te vat:

In Augustine's mature thought there is no trace of a theory of the state as concerned with man's self-fulfilment, perfection, the good life, or with 'educating' man towards such purposes. Its function is more restricted: it is to council out at least some of the effects of sin ... Political authority serves to remedy the conflict, disorder and tensions in society (Markus, 1988:94-95).

Dat daar egter enkele belangrike uitsonderings op hierdie algemene reël voorkom, sal weldra in die verdere bespreking duidelik word. 


\subsection{Die staat as regsordening}

Oor die vraag na die plek en betekenis wat die begrip geregtigheid in die staatsleer van Augustinus inneem, loop die menings van navorsers grootliks uiteen. Daar is byvoorbeeld diegene wat van mening is dat Augustinus nie die filosofie (van Cicero) volg waar geregtigheid as hoeksteen en die siel van die politiek gesien word nie (Deane, 1963:117118; Engelbrecht, 1985:86-87, 91-96; Ruokanen, 1988:29; Rist, 1999: 219). Volgens hierdie visie oordeel Augustinus dat die ware geregtigheid (vera iustitia) net in die Godsryk te vind is, en daarom eerder die voorwerp van geloof en hoop is as wat dit 'n aardse realiteit is (Ruokanen, 1988:30-32).

Aan die ander kant is daar diegene wat van oordeel is dat geregtigheid die hooftema van die De civitate dei is (Fortin, 1997:41) en dat Augustinus alles behalwe Machiavelliaans of Hobbeaans in sy staatsbeskouing is. Geregtigheid bly vir altyd die ideaal, hoewel dit op aarde onbereikbaar is en om komplementering vra.

Fortin (1997:48) vat laasgenoemde standpunt soos volg saam:

Augustine's reformulation of Cicero's definition has frequently been taken to mean that he regarded the state as an amoral entity with no stake whatever in the character of its citizens, that politics has nothing to do with ethics, and that Augustine is best read as a Machiavellian before the letter, a champion of 'value-neutrality', or a precursor of modern social science positivism. To say this, however, is gravely to misconstrue Augustine's thought. Augustine does not disagree with Cicero's definition.

In die benadering wat hierna bespreek word, word by die standpunt van Fortin aansluiting gevind, toegelig met wat Augustinus in die algemeen oor geregtigheid opmerk en voorts met wat hy spesifiek oor 'n regverdige oorlog beweer.

Watter standpunt huldig Augustinus oor geregtigheid?

Geregtigheid - veral verstaan as gelykberegtiging (DCD 19:21) - is inderdaad 'n sleutelbegrip in die Augustiniaanse staatkundige denke. Wél erken hy dat ware geregtigheid in hierdie lewe eerder in sondevergifnis as in volmaakte deugsaamheid bestaan (DCD 19:27), maar daarmee het hy die begrip aardse geregtigheid nie uitgerangeer nie. Diegene wat goed leef, sê hy, doen reg en geregtigheid; goed lewe is om God te gehoorsaam (DCD 17:4) - en gehoorsaamheid is vir Augustinus so ongeveer die moeder van alle deugde (DCD 14:12). Augustinus beskou (Christelike) regeerders daarom as gelukkig "as hulle regverdig regeer" (DCD 5:24), as hulle hul mag diensbaar maak aan God se 
majesteit deur hulle mag te gebruik vir die groots moontlike verbreiding van sy diens, as hulle God vrees, liefhet en dien. Terselfdertyd ag hy hulle wat aan die uiterste grense van die aarde woon, nie ontslae van die plig om reg en geregtigheid te doen nie (DCD 17:4; vgl. egter 19:21). Diegene wat volhardend reg en geregtigheid op aarde doen, sal in die laaste oordeel nie verdoem word nie (DCD 17:4).

Geregtigheid is dus vir Augustinus 'n bepalende begrip. Remota iustitia, quid sunt regna nisi magna latrocinia? vra hy aan die begin van $D e$ civitate dei 4:4. Hierop volg dan die beroemde tweegesprek van Alexander die Grote en die seerower waartydens laasgenoemde teenoor Alexander opmerk: Omdat ek die see met 'n klein skippie onveilig maak, word ek 'n rower genoem, terwyl u wat dit met 'n groot vloot doen, 'n heerser genoem word! - 'n opmerking wat volgens Fortin (1997:51) 'n element van waarheid bevat ( $\mathrm{nl}$. dat die mens net so goed is as die saak waarvoor hy hom beywer).

Augustinus erken dat die ware geregtigheid nooit by Rome - en by enige aardse koninkryk - te vind was nie en dat dit slegs in die stad van God aangetref word (DCD 2:21).

Augustinus se bemoeienis met die geregtigheidskonsep blyk verder ook uit sy hantering van die bellum iustum (vir 'n kort samevatting, met bronverwysings, vgl. Van Wyk, 1984:59-61; verder ook Markus, 1983:113; Langan, 1991:169-189; Holmes, 1999:323-344).

Wat Augustinus beweeg het om die bellum iustum-teorie te ontwerp, was sy gevoel van verantwoordelikheid vir die lot van hierdie wêreld, sy belangstelling vir die bewaring van die morele sosiale orde (Langan, 1991:175) en sy verlange om die Romeinse Ryk, wat die kerk en regsorde beskerm het, te steun in sy stryd teen die opkomende Gote, Vandale en Hunne. Daarby het die verwyt van die heidense burgers, naamlik dat Christene weens hulle geweldloosheid geen goeie staatsburgers kan wees nie, ook 'n rol gespeel.

Volgens Augustinus is oorlog deel van die huidige sonde-orde (DCD 19:7). Wanneer hy daarom in De civitate dei 19:7 na 'n regverdige oorlog verwys, dan vind dit plaas binne die konteks van 'n probleem - oorloë moes eintlik nie plaasgevind het nie. Dit is die ongeregtighede van die teenstanders wat die wyse mense dwing om oorloë te voer (DCD 19:7,15). Oorloë mag nooit 'n doel op sigself word nie. Vrede is die doel van oorlog, lui dit in DCD 19:12. "Elkeen streef na vrede deur oorlog te maak, maar niemand streef na oorlog deur vrede te maak nie." (Augustinus se beroemde brief aan Bonifacius [418 n.C.] bevat dieselfde 
inhoud: Non enim pax quaeritur ut bellum excitetur, sed bellum geritur ut pax aquiratur.)

Augustinus stel drie voorwaardes vir die bellum iustum:

- Legitima auctoritas (wettige owerheid)

- Iusta causa (juiste oorsaak)

- Recta intentio (regte motief)

Vir Augustinus weeg die laaste voorwaarde die swaarste, sodat sy oorlogsetiek hoofsaaklik as 'n gesindheidsetiek bestempel kan word die gevolge van 'n oorlog word nie in die voorwaardes bespreek nie. Afgesien van die ius ad bellum het Augustinus natuurlik ook 'n ius in bello erken. Ook dit wat ín 'n oorlog plaasvind, is nie waardevry nie (vgl. DCD 5:26).

Die konsep van die bellum iustum is 'n teorie wat, hoewel sekere nuanserings en verfynings later aangebring is, die algemene standpunt van Christene oor oorlog tot vandag toe verteenwoordig. Tog is dit ' $n$ teorie wat, te meer in 'n eeu van kernwapens, met belangrike kritiese vrae omring word - vrae wat egter nie hier verder bespreek word nie (vgl. Van Wyk, 1984:136-152; Van Wyk, 1986:145-151).

\subsection{Die staat as vredesordening}

Die vraag kan gestel word of Augustinus se vredesbeskouing enige sosiaal-politieke relevansie besit (vgl. Fuchs, 1965; Laufs, 1973, Budzik, 1988; Geerlings, 1997). In De civitate dei 19:11 aksentueer Augustinus die betekenis van vrede:

Vrede is so 'n goeie ding dat daar ook op die gebied van die aardse en verganklike (dinge) niks aangenamer te hoor, niks begeerliker te wens en ten slotte niks voortrefliker te vind is nie.

Terwyl Augustinus aanvanklik in sy verklaring van die Bergrede geoordeel het dat volle vrede op aarde bereikbaar is, het hy later bevind dat dit eers in die hemel bereik sal word (Laufs, 1973:36-37). "Die hoogste goed van die (hemelse) stad is die vrede van die ewige lewe of die ewige lewe in vrede" (DCD 19:11).

Geerlings (1997:224) vestig tereg die aandag daarop dat Augustinus die tema van vrede behandel binne die konteks van geluk. In De civitate dei 19:1 merk Augustinus op dat 'n mens om geen ander rede filosofeer as om gelukkig te wees nie en "dit wat hom gelukkig maak, is self die hoogste goed"; die hoogste goed is met ander woorde die rede vir filosofering. En die hoogste goed, so het ons reeds gesien, bestaan vir 
Augustinus in "vrede in die ewige lewe of ewige lewe in vrede" (DCD 19:11). Wie daarin slaag om hierdie lewe op die toekomstige te rig, kan nou reeds gelukkig genoem word - al is dit in hoop (DCD 19:20). Die verloste het in hoop deel aan die pax perfecta; die civis civitatis dei orden hulleself in fide onder die wil van God en bewaar daarmee die Godgewilde ordening - en so ontstaan vrede (Laufs, 1973:51). Die vrede is hier op aarde nog onvolkome want die pietas (die fondament van vrede) is nog onvolkome en eers eenmaal in die voleinding word dit pax perfecta.

Die verdeelde mensheid het ' $n$ verdeelde strewe na vrede. Die mens het egter van nature 'n verlange na societas en daarmee na concordia en pax (DCD 14:1), maar die mens het hom in hoogmoed van God afgewend en slegs die genade van God in Christus kan weer die strewe na vrede herstel.

Vrede bestaan vir Augustinus in die balans van orde en die regte orde bestaan in "die rangskikking van gelyke en ongelyke dinge" (DCD 19:13). Wat Augustinus hieronder verstaan, verduidelik hy aan die hand van 'n vredestabel aan die begin van De civitate dei 19:13 soos volg (waarin ook sy antropologie duidelik word) (vgl. Laufs, 1973:88-124):

- Die vrede van die liggaam (wat bestaan in die geordende saamgaan van die liggaamsdele).

- Die vrede van die nie-redelike siel (bestaan in die geordende rus van sy strewes).

- Die vrede van die redelike siel (bestaan in die ooreenstemming van ken en doen).

- Die vrede tussen liggaam en siel (bestaan in die goed geordende en harmoniese syn en welsyn van 'n lewende wese).

- Die vrede tussen mens en God (bestaan in die goed geordende gehoorsaamheid van geloof aan die ewige wet).

- Die vrede tussen mens en mens (bestaan in goed geordende eendrag).

- Die vrede van 'n huisgesin (bestaan in goed geordende eendrag tussen hulle wat bevele gee en hulle wat dit gehoorsaam).

- Die vrede tussen staatsburgers (bestaan in die goed geordende eendrag tussen bevelvoerders en gehoorsames). 
- Die vrede van die hemelse stad (bestaan in die perfekte geordende en harmoniese genieting van God en mekaar in God).

Soos in die geval van sy liefdesbegrip (siel bo liggaam, mens bo ding, God bo mens), maak Augustinus ook in sy vredesbegrip die ordebegrip vrugbaar (Laufs, 1973:49, 70). Die perfekte orde word telkens gevind waar die laere aan die hoëre onderwerp word. Wanorde, onvrede en oorlog ontstaan waar hierdie orde(s) versteur word.

Solank die twee stede op aarde nog gemeng is, maak die Christen van die vrede van Babel gebruik (DCD 19:26) en werk hy selfs met ander daaraan mee. Augustinus ken dus nie soiets soos Christelike politiek of 'n Christelike staat nie (Ruokanen, 1988:33; De Kruif, 1994:61; Fortin, 1997:59-61).

Geerlings (1997:222-224) wys Fuchs (oorspr. 1926) se benadering af waarvolgens Augustinus vrede eensydig op die toekomstige lewe betrek en hy beaam Laufs (1973) se benadering waarvolgens Augustinus se vredesbegrip ook polities relevant is, hoewel Geerlings die vraag stel of Augustinus voldoende daarin geslaag het om die teenswoordige en toekomstige vrede genoegsaam op mekaar te betrek. Die feit dat Augustinus nogtans die tema van vrede vir die aardse ryk en die sosiale etiek vrugbaar probeer maak het, moet as sodanig waardeer word.

\subsection{Die staat as vryheidsordening}

Wanneer Augustinus se vryheidsbeskouing nagegaan word, val dit dadelik op dat hy dit (veral) hanteer binne die raamwerk van die individuele en nie die politieke etiek nie. Sy sonde- en genadebeskouing neem in hierdie opsig 'n sentrale plek in, te meer in sy latere antiPelagiaanse fase. Die menslike wil is die oorsaak van die bose. Daar bestaan tweespalt tussen wilsvryheid en daadvryheid. Van nature verkeer die mens in slawerny en ware vryheid kom slegs van God en die genade van Christus (vgl. Peetz, 1997:63-86).

In sy vryheidsbeskouing het Augustinus die fatalisme van die Manicheïsme afgewys wat die soewereiniteit van God ten koste van die vryheid van die mens gehandhaaf het, asook die liberalisme van die Pelagianisme wat die vryheid van die mens ten koste van die soewereiniteit van die God beklemtoon het.

Het Augustinus die tema van godsdiensvryheid geken? Het die staat 'n positiewe taak ten opsigte van die kerk en die Christelike godsdiens? Augustinus (DCD 19:4) oordeel dat die staat die kerk nie moet verhinder nie, maar soms ook moet bevorder - ten minste wat die éénheid van die kerk betref. In hierdie verband kan verwys word na Augustinus se 
goedkeuring (en moontlike mede-inisiëring) van die staatkundige vervolging van die Donatiste - iets waaroor navorsers baie krities oordeel (vgl. Frend, 1952:227-243; Bonner, 1986:237-275; Markus, 1988:133153; Höffe, 1997:286). Die Donatiste het - soos Tertullianus - staat en kerk, Atene en Jerusalem, so ver as moontlik uit mekaar gehou. Alle nadruk het vir hulle - soos vir Ciprianus - op die heiligheid en reinheid van die kerk geval (Van Oort, 1990:78). Hulle kon dus nie vrede hê met Christene en biskoppe wat owerheidsgesag blindelings gevolg en verraad teenoor die evangelie gepleeg het nie.

Keiser Diocletianus het met 'n wrede vervolging teen die Christene begin (303-305 n.C.). Christene is beveel om hulle heilige boeke, waaronder ook die Bybel, in te lewer waarna dit dan verbrand is. Die dapperes (latere Donatiste) het geweier en lafhartiges (veral Katolieke Christene) het die bevel gehoorsaam. So het daar in 312 'n breuk in die NoordAfrikaanse kerk ontstaan wat vir drie eeue sou duur en eers deur die indringing van die Islam beëindig sou word. Die Donatiste het hulle beywer vir 'n smettelose kerk sonder samewerking met die owerheid. Hulle het die heiligheid van die kerk beklemtoon maar ten koste van sy eenheid (vgl. Frend, 1952; Brown, 1969:213-258).

Waar Augustinus aanvanklik die standpunt gehuldig het dat die staat geweld kon gebruik om die Katolieke te beskerm, het hy later - in die geval van die Donatiste - staatsgeweld aanvaar waarvolgens die Donatiste gedwing kon word om Katolieke te word (Rist, 1999:240). Terwyl heidene opgeroep is tot geloof (deur die kerk), is die Donatiste teruggeroep na die kerk - en die staat moes hulle daartoe dwing.

Wanneer Augustinus se houding teenoor die Donatiste beoordeel word, moet natuurlik verreken word dat hy oor 'n lang periode met hulle gedebatteer en gepolemiseer het en dat hy ten einde laaste tot die oortuiging gekom het dat staatsdwang (ter wille van die eenheid van die kerk) noodsaaklik was (cf. Sizoo, 1957:230-254). Rist (1999:231) wys hier op 'n opvallende inkonsekwensie by Augustinus: ons lees nêrens daarvan dat hy ook van die staat verwag het om ten opsigte van die Manicheïste dwang te gebruik nie.

'n Ander aspek van Augustinus se vryheidsopvatting is die vraag hoe hy oor slawerny geoordeel het (vgl. Rist, 1999:236-239). Klaarblyklik aanvaar hy slawerny, al verbind hy dit duidelik met die sondeval van die mens (DCD 18:2; 19:15). Slawerny is met ander woorde onvermydelik in 'n gevalle wêreld. Augustinus het nie belanggestel in die institusionele hervorming van slawerny nie. Base moet hulle slawe goed behandel en moet vry van magslus wees. Slawe kan moreel vry wees en mag slegs 
ongehoorsaam wees as die eienaar die Tien Gebooie oortree. Volle vryheid is uiteindelik 'n eskatologiese begrip.

Augustinus se vryheisbegrip is sterk individueel gedefinieer en eskatologies gefokus, sonder besondere aandag aan politieke en strukturele vryheid.

\subsection{Die staat as voorlopige ordening}

Augustinus se eskatologiese perspektief het sonder twyfel sy staats- en kerkbeskouing diepgaande beïnvloed. Die Christelike hoop op die hemelse stad relativeer enersyds alle hoop op verganklike aardse koninkryke (Markus, 1988:157,159), maar aktiveer andersyds die Christen in sy werk in die aardse ryk (Markus, 1988:167). 'n Christen leef en werk binne die verwysingsraamwerk van die koninkryk van God, maar die ware geregtigheid en ware vrede bly uiteindelik eskatologiese verwagtings.

Wat bepalend is vir 'n samelewing, hang van die gerigtheid van die wil van individue af. Die vraag is: leef hulle uit liefde vir die Skepper of uit liefde vir die skepsel, leef hulle vir die ryk van God of vir die ryk van die duiwel (Ruokanen, 1988:34)?

Die Christen is vreemdeling in hierdie wêreld op weg na die beloofde vaderland. Die Christelike hoop mag nie in politieke strukture vasgevang word nie (Horn, 1995:114). Geen tydelike samelewing kan 'n volle replika van die hemelse stad wees nie, hoogstens miskien 'n dowwe refleksie daarvan (Burt, 1997:198). Die staat, soos ook die totale werklikheid, is deel van ' $n$ voorlopige en verbygaande bedeling. Daar steek waarheid in die volgende opmerking van TeSelle (1991:160), hoewel dit in 'n sekere sin tog 'n eensydigheid bevat:

The earthly future has significance for Augustine's eschatology only religiously, not politically, because it did not occur to him that there could be a political contribution to the eschaton.

Augustinus is egter nie 'n voorstander van 'n totale annihilasie van die geskape werklikheid nie. Die eindoordeel beteken vir hom nie die algehele ondergang van hierdie wêreld nie, maar wel die verandering van gedaante (DCD 20:14). Die hoedanighede van die verderflike elemente sal ten gronde gaan, maar die wese van die dinge ontvang nuwe hoedanighede (DCD 20:16). 


\section{Samevatting}

Augustinus pas nie netjies in by die genoemde ou en moderne staatkerkmodelle nie. Elke tipering hou ook die gevaar van vertekening en vereensydiging in en moet daarom omsigtig gehanteer word. Augustinus het binne die konteks van sy tyd 'n eie weg gegaan en 'n eie antwoord probeer vind (Markus, 1988:52-57).

Wel kan gesê word dat sy politieke realisme hom bewaar het van fatalisme en utopisme (TeSelle, 1970:271-272) en dat hy kwiëtisme en 'n (kerklike) teokrasie afgewys het en kerklike (of eerder Christelike) invloed in die samelewing voorgestaan het (TeSelle, 1970:277).

Sy sonde- en genadeleer, asook sy mens- en verlossingsleer, het sy staat- en kerkbeskouing diepgaande beïnvloed. Dit moet waardeer word dat hy die temas van geregtigheid, vrede en vryheid in ' $n$ mindere of meerdere mate vir die staatsleer probeer vrugbaar maak het. Hoofsaak is egter sy prioritisering van die koninkryk van God as sinontsluiting van die geskiedenis van die kerk en wêreld.

\section{Evaluering}

Uiteindelik moet getrag word om die visie van Augustinus krities te beoordeel, eers negatief en daarna positief.

Wat die negatiewe kritiek betref, kan op die volgende gewys word:

- Augustinus het nie die onderskeiding tussen individuele (private) en strukturele (publieke) etiek geken en gehanteer nie en gevolglik is sy beskouings hoofsaaklik vanuit 'n privaatmoraal ontwikkel.

It is striking that when Augustine defends the exercise of coercive power by the secular authority in the religious sphere, he always does so in a vocabulary of persons rather than of institutions (Markus, 1988:149).

Sy geregtigheidsbegrip (Höffe, 1997:279) en sy vredesbegrip (Rist, 1999:232) word gekenmerk deur 'n aanpak oorwegend vanuit die individuele etiek sonder duidelike strukturele kontoere. Dieselfde geld van sy vryheidsbegrip, soos byvoorbeeld uit sy hantering van slawerny gesien kan word.

- Hoewel Augustinus huiwerig was vir die aanwending van staatsmag in godsdienstige sake, is sy uiteindelike aanvaarding daarvan ten opsigte van die Donatiste - wat nie dwaalleraars (heretici) nie maar skeurmakers (skismatici) was - afkeurenswaardig. Dit is nie deel van die staatstaak om godsdiens te bevorder nie. 
- Augustinus het nie die twintigste-eeuse aksent op die profetiese roeping van die kerk in die samelewing teenoor die staat geken nie hoewel hy in sy preke sosiale vraagstukke aangespreek en in sy daaglikse regspraak (Van der Meer, 1949:284 e.v.) sy Christelike roeping uitgeleef het. Uiteraard kan die profetiese roeping van die kerk oorbeklemtoon word sodat die kerk se eintlike taak as sosiale en politieke hervorming gesien word, maar dit kan ook onderbeklemtoon word en die vraag na 'n swyende kerk na vore roep.

Aan die positiewe kant kan die volgende opgemerk word:

- Augustinus het ons - veel meer as sy voorgangers - geleer om oor die staatkunde te teologiseer en sodoende het hy politieke nadenke gestimuleer (Dyson, 1998:xv-xxxiii). Sy standpunt kom daarop neer dat die teokratiese ideaal (in 'n plurale samelewing) geen steun in die Nuwe Testament vind nie, tensy dit bedoel is as geloofsbelydenis dat God regeer en dat sy koninkryk aan't kom is.

- Augustinus het ons ook geleer om te sosialiseer, dit wil sê om die temas van geregtigheid en vrede as sentrale temas van die sosiale etiek aan die orde te stel (vgl. Douma, 1984:40-41) - ook ten opsigte van nie-Christelike state. Hoewel Augustinus in die uitwerking van hierdie temas nie ten volle geslaag het nie, is sy aanwending daarvan ten volle geregverdig.

- Augustinus het ons verder geleer om te relativeer; hy het soos geeneen voor hom daarop gewys dat die koninkryk van God alle aardse koninkryke relativeer, herwaardeer en herrangskik tot hulle juiste proporsies. Nêrens mag 'n aardse ryk verabsoluteer of vergoddelik word nie (vgl. Markus, 1988:157,159). Soos Noordmans (1933:104) in hierdie verband tereg opmerk:

Men moet oud-testamentisch leren denken. Daar spiegelt het eeuwige zich in het tijdelijke. Daar is politiek zonder afgoden te zien. Staatsvergoding moet ophouden ...

Hierdie siening van Augustinus is natuurlik van die grootste belang vir Suid-Afrika, sowel vir die ou Suid-Afrika waar die apartheidsmonster alles ingesluk het (ook die kerk), as vir die nuwe Suid-Afrika waar alles (van sport tot kerk) in diens gestel word van "nasiebou".

- Augustinus leer ons ook om te eskatologiseer, om alles op aarde te sien in die lig van die komende Godsryk - hoewel erken moet word dat Augustinus nie genoegsaam daarin geslaag het om die verhouding tussen aardse ryk (hiernoumaals) en hemelse ryk (hiernamaals) deursigtig te maak nie. Ons erken (vandag) dat mense nie die 
koninkryk van God kan bou nie, maar hulle kan wel in die samelewing daaraan diensbaar wees, die beginsels daarvan uitleef, in die rigting daarvan leef en die voleinding daarvan afwag as geskenk van God.

- Uiteindelik het Augustinus ons ook geleer om op die juiste wyse te kontekstualiseer. Vir die sosiale etiek is dit van die uiterste belang om telkens die verskuiwende sosiopolitieke konteks in die teologiese besinning te verreken. Die val van Rome in 410 het tot 'n totale herbesinning by Augustinus gelei, soos wat die Europese teologie na die Tweede Wêreldoorlog (1945) en die Afrikaanse teologie na die val van apartheid (1994) ook tot 'n nuwe oriëntering aanleiding gegee het. In hierdie herbesinning behoort die koms van die koninkryk van God 'n sentrale plek in te neem - anders word die les van die verlede nooit geleer nie.

Kontekstualisering impliseer natuurlik nie dat aan die konteks voorrang bo die Teks verleen word nie, maar wel dat die konteks in die teologiese besinning deeglik verreken word. Teologie behoort immers nie wêreldvreemd beoefen te word nie. Te lank is die teologie beginselvas maar konteksloos beoefen.

\section{Slotbeskouing}

Die grootste bydrae wat Augustinus gelewer het, ten minste vir die SuidAfrikaanse konteks, moet gesoek word in sy sentraalstelling van die koninkryk van God. Die koninkryk van God is groter, belangriker en duursamer as enige kerk of enige staat - en mag dus nie met byvoorbeeld die kerk vereenselwig word nie (wat Augustinus wel hier en daar gedoen het [vgl. DCD 8:24; 13:16; 20:21]). Die kerk kan wel 'n (floue) gestalte van die koninkryk wees. Selfs die staat mag 'n dowwe heenwysing na die koninkryk bevat in soverre iets van die geregtigheid, vrede en vryheid van die koninkryk in die staat gestalte aanneem.

Wat ewig bestaan, is nie die kerk of staat nie (contra Engelbrecht, 1988:103), maar die koninkryk, die nuwe samelewing soos deur God regeer, die nuwe hemel en die nuwe aarde, waar God alles vir almal sal wees (1 Kor. 15:28) en waar ons God sal sien (Op. 22:4).

\section{Bibliografie}

AUGUSTINUS, A. 1983. De stad van God. Baarn : Ambo. (Vert. G. Wijdeveld.) (Afgekort as DCD, as verwysing na De civitate dei.)

AUGUSTINUS: Bauer, J.B., ed. 1992. Corpus Scriptorum Ecclesiasticorum Latinorum. Wenen : Hölder-Pichler-Tempsky (CSEL 40:1: De civitate dei).

AUGUSTINUS: Migne, J-B., ed. 1841-1842. Patrologiae Cursus Completus (32-47). Parys : Migne (PL 41:13-804: De civitate dei). 
BAYNES, N.H. 1936. The political ideas of St. Augustine's "De civitate dei". London : Bell.

BONNER, G. 1986. St. Augustine of Hippo: Life and controversies. Norwich : The Canterbury Press. (Oorspr. 1963.)

BROWN, P. 1969. Augustine of Hippo: A biography. Berkeley : University of California Press.

BROWN, P. 1972. Political society (In Markus, R.A., ed. Augustine: A collection of critical essays, New York : Anchor Books.)

BUDZIK, S. 1988. Doctor pacis: Theologie des Friedens bei Augustinus. Innsbruck : Tyrolia-Verlag.

BURT, D.X. 1997. Cain's city: Augustine's reflections on the origins of the civil society. (In Horn, C. Hrsg. Augustinus: De civitate dei. Berlin : Akademie Verlag. p. 195-210.)

DEANE, H.A. 1963. The political and social ideas of Saint Augustine. New York : Columbia University Press.

DE KRUIJF, G.G. 1994. Waakzaam en nuchter: Over christelijke ethiek in een democratie. Baarn : Ten Have.

DCD

kyk Augustinus, A. 1983.

DOUMA, J. 1984. Politieke verantwoordelijkheid. Kampen : Van den Berg.

DUCHROW, U. 1970. Christenheit und Weltverantwortung: Traditionsgeschichte und systematische Struktur der Zweireichelehre. Stuttgart : Ernst Klett.

DYSON, R.W. (ed. \& translater.) 1998. Augustine: The city of God against the pagans. Cambridge : Cambridge University Press.

ELSHTAIN, J.B. 1995. Augustine and the limits of politics. Notre Dame, Ind. : University of Notre Dame Press.

ENGELBRECHT, B. 1985. Augustinus se politieke "realisme" en sy "neutrale" definisie van die staat. (In Landman, C. \& Whitelaw, D.P., reds. Oorspronge in oënskou: Opstelle oor die vroeë kerk ter ere aan J.A.A.A. Stoop op sy sestigste verjaardag. Pretoria : Unisa. p. 86-105.)

FAHEY, M.A. 1992. Augustine's ecclesiology revisited. (In McWilliam, J. Augustine: From rhetor to theologian. Waterloo/Ontario : Wilfrid Laurier University Press. p. 173-181.)

FIGGIS, J.N. 1921. The political aspects of St. Augustine's "City of God". London : Longmans.

FORTIN, E.L. 1997. Justice as the foundation of the political community: Augustine and his pagan models. (In Horn, C. Hrsg. Augustinus: De civitate dei. Berlin : Akademie Verlag. p. 41-62.)

FREND, W.H.C. 1952. The Donatist church: A movement of protest in Roman North Africa. Oxford : Clarendon.

FRIBERG, H.D. 1944. Love and justice in political theory: A study of Augustine's definition of the commonwealth. Chicago : Chicago University Press.

FUCHS, H. 1965 [1926]. Augustin und der antike Friedensgedanke: Untersuchungen zum neunzehnten Buch der civitas Dei. Berlin : Weidemann. (Oorspr. 1926.)

GEERLINGS, W. 1997. De civitate dei xix als Buch der Augustinische Friedenslehre. (In Horn, C. Hrsg. Augustinus: De civitate dei. Berlin : Akademie Verlag. p. 211233.)

GRABOWSKI, S.J. 1957. The church: Introduction to the theology of Saint Augustine. London : Herder Book. 
HÖFFE, O. 1997. Positivismus plus Moralismus: zu Augustinus' eschatologisher Staatstheorie. (In Horn, C. Hrsg. Augustinus. : De civitate dei. Berlin : Akademie Verlag. p. 259-287.)

HOFMANN, F. 1933. Der Kirchenbegriff des hl. Augustinus in seinen Grundlagen und seiner Entwicklung. München : Kaiser.

HOLMES, R.L. 1999. St. Augustine and the just war theory. (In Matthews, G.B., ed. The Augustinian tradition. London : University of California Press. p. 323-344.)

HORN, C. 1995. Augustinus. München : Beck.

LANGAN, J. 1991. The elements of St. Augustine's just war theory. (In Babcock, W.S., ed. The ethics of St. Augustine. Atlanta/Georgia : Scholars Press. p. 169189.)

LAUFS, J. 1973. Der Friedensgedanke bei Augustinus: Untersuchungen zum xix Buch des Werkes De civitate dei. Wiesbaden : Franz Steiner Verlag.

MARKUS, R.A. 1983. Saint Augustine's views on the just war. Studies in Church History, 20:1-13.

MARKUS, R.A. 1988. Saeculum: History and society in the theology of St. Augustine. Cambridge : University Press.

MARSHALL, R.T. 1952. Studies in the political and socio-religious terminology of the De civitate dei. Washington, DC : Catholic University of America Press.

NIEBUHR, R. 1986. Augustine's political realism. (In McAfee Brown, R., ed. The essential Reinhold Niebuhr. Selected essays and addresses. New Haven : Yale University Press. p. 123-141.)

NOORDMANS, O. 1933. Augustinus. Haarlem : Bohn.

PEETZ, S. 1997. Augustine über menschliche Freiheit (Buch V). (In Horn, C. Hrsg. Augustinus: De civitate dei. Berlin : Akademie Verlag. p. 63-86.)

RATZINGER, J. 1954. Volk und Haus Gottes in Augustinus Lehre von der Kirche. München : Zink.

RIST, J.M. 1999. Augustine: Ancient thought baptized. Cambridge : University Press.

RUOKANEN, M. 1988. Augustin und Luther über die Theologie der Politik. Kerugma und Dogma, 34(1):22-41.

SIZOO, A. 1957. Augustinus: Leven en werken. Kampen : Kok.

TeSELLE, E. 1970. Augustine the theologian. Londen : Burns \& Oates.

TeSELLE, E. 1991. Toward an Augustine politics. (In Babcock, W.S., ed. The ethics of St. Augustine. Atlanta/Georgia : Scholars Press. p. 147-168.)

VAN BAVEL, T.J. 1976. Wat voor kerk kies je? De ruimheid van Augustinus' ecclesiologie. Tijdschrift voor Theologie, 16:355:375.

VAN DER MEER, F, 1949. Augustinus de zielzorger: Een studie over de praktijk van een kerkvader. Utrecht: Het Spectrum.

VAN OORT, J. 1990. Augustinus over de kerk. (In Van't Spijker, W. et al., red. De kerk: Wezen, weg en werk van de kerk naar reformatorische opvatting. Kampen : De Groot Goudriaan. p. 65-94.)

VAN WYK, J.H. 1984. Etiek van vrede: 'n Teologies-etiese evaluering van die Christenpasifisme. Cabo : Stellenbosch. (Oorspr. 1974.)

VAN WYK, J.H. 1986. Gesindheid en gestalte. Pretoria : NG Kerkboekhandel.

VAN WYK, J H. 1991. Moraliteit en verantwoordelikheid: Opstelle oor politieke etiek. Potchefstroom : PUCHO.

VAN WYK, J.H. 1998. Etiek in eenvoud: Gesprekke oor morele vraagstukke. Potchefstroom : PTP.

VAN WYK, J.H. 1999. Lewe in liefde: Moraliteit vir die markplein. Potchefstroom : PUCHO/IRS. 


\section{Kernbegrippe:}

geregtigheid

kerk (Augustinus se siening)

staat (Augustinus se siening)

stad van God

verhouding staat en kerk (by Augustinus)

\section{Key concepts:}

Church (Augustine's view)

city of God

justice

relation: state and church

state (Augustine's view) 